\title{
Determination of pyrrolizidine alkaloids levels in Symphytum asperum
}

\author{
SHYLOCK O. ONDUSO ${ }^{1}$, MARGARET M. NG ${ }^{\circ}$ ANG $^{`} \mathrm{~A}^{2, \bullet}$, WACEKE WANJOHI ${ }^{3}$, AHMED HASSANALI ${ }^{2}$ \\ ${ }^{1}$ School of Pure and Applied Sciences, Kenyatta University. Nairobi, Kenya \\ ${ }^{2}$ Department of Chemistry, Kenyatta University. Nairobi, Kenya. •email: nganga.margret@ku.ac.ke \\ ${ }^{3}$ Department of Agricultural Science and Technology, Kenyatta University. Nairobi, Kenya
}

Manuscript received: 30 October 2016. Revision accepted: 4 April 2017.

\begin{abstract}
Onduso SO, Ng'ang'a MM, Wanjohi W, Hassanali A. 2017. Determination of pyrrolizidine alkaloids levels in Symphytum asperum. Biofarmasi J Nat Prod Biochem 15: 65-73. The levels of the pyrrolizidine alkaloids (PAs) in the roots and leaves of comfrey (Symphytum asperum Lepech) from two agro-ecological zones in Kenya, Kiambu, and Kisii counties during wet (April 2012) and the dry (September 2012) seasons were determined in the present study. The samples were dried beneath the shade for four weeks, continued with ground and extraction of the PAs by applying different solvent systems. The result displayed no significant difference in the percentage of dry weights for the leaves and the roots samples collected from Kisii and Kiambu counties during the wet and dry seasons ( $>0.05$ at $95 \%$ confidence limit). Gas Chromatography (GC) combined with a Mass spectrometer (MS) was used to analyze the samples and characterize and quantify major components. Among four PAs identified in the root samples (echimidine (7), 7acetyllycopsamine (17), 3'-acetyllycopsamine (18), triangularine (19), and heliosupine (24)), a significant amount of 7Acetyllycopsamine (17) was evident during the wet season as compared to the dry season $(\mathrm{p}=0.033, \alpha=0.05, \mathrm{t}$-test). The other pyrrolizidine alkaloids measured between the two seasons did not vary significantly ( $>0.05, \alpha=0.05$, t-test). All the compounds reported in the root samples are associated with toxicity, and their values exceed the tolerable levels recommended by relevant regulatory bodies in various countries. One of the most toxic PAs, echimidine (7), was found in all the root samples. However, the leaf samples showed PAs level below detectable limits using GC-MS. Further study is needed to examine whether PAs are produced from the leaves collected at different maturation levels and from a broader plant profile. Furthermore, it is necessary to know the levels of a particular PA and related analogs in a larger profile of the plants cultivated in other agroecological zones in Kenya. A study on the toxicity of heliosupine (24) is of future interest since it exists in significant amounts, yet such studies have not been done on this constituent. Also, preparative isolation of the PAs should be performed to provide reference standards in other quantification facilities that utilize Gas Chromatography because GC-MS is a rather expensive method.
\end{abstract}

Keywords: Alkaloids, Symphytum asperum, pyrrolizidine

\section{INTRODUCTION}

Pyrrolizidine alkaloids (PAs), compounds identified in plants, consist of two five-membered rings which share nitrogen atoms at position 4 (Crews et al. 2009). Typically, a hydroxy methylene group is attached at C-1 and a hydroxyl group at C-7 (Molyneux et al. 1991). This structure forms the necine base (1), with known major representative structures including retronecine (2), heliotridine (3), platynecine (4), and otonecine (5). Retronecine and heliotridine are both enantiomers at C-7 (Fu et al. 2001; FAO 2010). The necines can either be saturated or possess a double bond in the 1,2 positions (Roeder 1999).

Esterification of one or both of the hydroxyl groups in the necine base by a necic acid gives its structural diversity, comprising monoesters, non-macrocyclic diesters, and macrocyclic diesters (Roeder 1999; Boppre 2011). The most prominent necic acids that form esters with necines are given in Table 1 (Roedar 1999).

Over 660 PAs and their N-oxides have been identified, and more are being identified in over 6000 plants belonging to some 13 families of the flowering plants (ANZFA 2001; Fu et al. 2001; Fu et al. 2004; COT 2008; Crews et al. 2009; Mei et al. 2010; Boppre 2011). This

number represents about $3 \%$ of all the species of flowering plants, in which three principal families are involved in the synthesis of Pas that are considered toxic. These families are Boraginaceae (all genera-including Symphytum), Compositae (tribes Senecionae and Eupatoriae), and Leguminoceae (genus Crotalaria) (Roeder 1999; Coulombe 2003; Fu et al. 2004; COT 2008; Pawar et al. 2010; CODEX 2011). A list of Symphytum spp. and the corresponding PAs produced are given in Appendix 1a (CODEX 2011). This study focused on the PAs obtained from comfrey (Symphytum asperum).

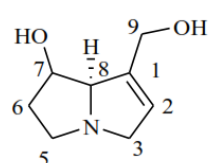

(1)

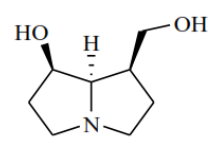

(4)

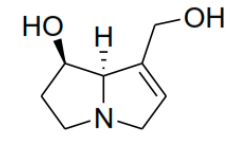

(2)

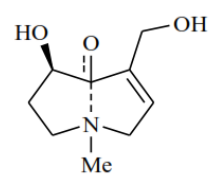

(5)

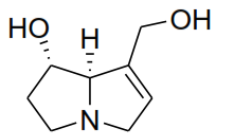

(3) 
Table 1. The most prominent necic acids

\section{General structure}

Monocarboxylic acids occurring in PAs

2-C Acids

5-C Acids

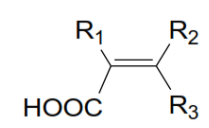

7-C Acids<smiles>[R]C([R])(C)[C@@]([R])(C(=O)O)C([R])(C)C</smiles>

7-C Acids

$\mathrm{Me}_{\mathrm{R}_{1}}^{\mathrm{HO}_{2} \mathrm{OH}^{\mathrm{R}_{1 / \prime \prime}}} \mathrm{CH}^{\mathrm{R}_{2}} \mathrm{Me}$
General names

Acetic acid (Ac)
$\mathrm{Me}-\mathrm{CO}_{2} \mathrm{H}$

$\begin{array}{lll}\mathbf{R}_{\mathbf{1}} & \mathbf{R}_{\mathbf{2}} & \mathbf{R}_{\mathbf{3}} \\ \mathrm{H} & \mathrm{Me} & \mathrm{Me} \\ \mathrm{Me} & \mathrm{Me} & \mathrm{H} \\ \mathrm{Me} & \mathrm{H} & \mathrm{Me} \\ \mathrm{CH}_{2} \mathrm{OH} & \mathrm{H} & \mathrm{Me}\end{array}$

$\begin{array}{lll}\mathbf{R}_{1} & \mathbf{R}_{2} & \mathbf{R}_{3}\end{array}$

$\begin{array}{lll}\mathrm{H} & \mathrm{H} & \mathrm{OH}\end{array}$

$\mathrm{H} \quad \mathrm{OH} \quad \mathrm{H}$

$\mathrm{OH} \quad \mathrm{OH} \quad \mathrm{H}$

$\mathrm{OH} \quad \mathrm{OMe} \quad \mathrm{H}$

$\mathbf{R}_{1} \quad \mathbf{R}_{2}$

$\mathrm{H} \quad \mathrm{OH}$

$\mathrm{OH} \quad \mathrm{H}$
Senecioic acid (Sen)

Tiglic acid (Tig)

Angelic acid (Ang)

Sarracinic acid (Sar)

(-)-Viridifloric acid

(+)-Trachelanthic acid

Echimidinic acid

Lasiocarpic acid

(-)-Trachelanthic acid (+)-Viridifloric acid

Dicarboxylic acids used for the construction of 12-membered macrocyclic PAs

10-C Acids<smiles>[R]C[C@@](O)(C(=O)O)[C@@H](C)[C@H]([R3])C(C(=O)O)=C([R12])C</smiles>

10-C Acids<smiles>[R3]C[C@](O)(C(=C)[C@@H](C([R])=[R])C(=O)O)C(=O)O</smiles>

10-C Acids<smiles>CC=C(C[C@@]1(CO)O[C@@](C)(C(=O)O)C1=O)C(=O)O</smiles>

10-C Acids<smiles>CC[C@H](C[C@H](C)[C@H](C)O)C(=O)O</smiles>

$\begin{array}{lll}\mathbf{R}_{1} & \mathbf{R}_{\mathbf{2}} & \mathbf{R}_{3}\end{array}$

$\mathrm{Me} \quad \mathrm{H} \quad \mathrm{H}$

$\mathrm{H} \quad \mathrm{Me} \quad \mathrm{H}$

$\begin{array}{lll}\mathrm{H} & \mathrm{H} & \mathrm{Me}\end{array}$

$\mathrm{Me} \quad \mathrm{H} \quad \mathrm{H}$

$\mathrm{H} \quad \mathrm{Me} \quad \mathrm{H}$

$\begin{array}{lll}\mathbf{R}_{\mathbf{1}} & \mathbf{R}_{\mathbf{2}} & \mathbf{R}_{3}\end{array}$

$\mathrm{Me} \quad \mathrm{H} \quad \mathrm{H}$

$\mathrm{H} \quad \mathrm{Me} \quad \mathrm{H}$

$\mathrm{Me}$

$\mathrm{H}$
$\mathbf{R}_{4}$

$\mathrm{H} \quad$ Senecinic acid

$\mathrm{H} \quad$ Integerrinecic acid

$\mathrm{H} \quad$ Senecivernic acid

$\mathrm{OH} \quad$ Isatinecic acid

$\mathrm{OH} \quad$ Retronecic acid

Seneciphyllic acid Spartioidinic acid Riddelliic acid

Erucifolinecic acid

Dicarboxylic acids used in the construction of 11-membered macrocyclic PAs
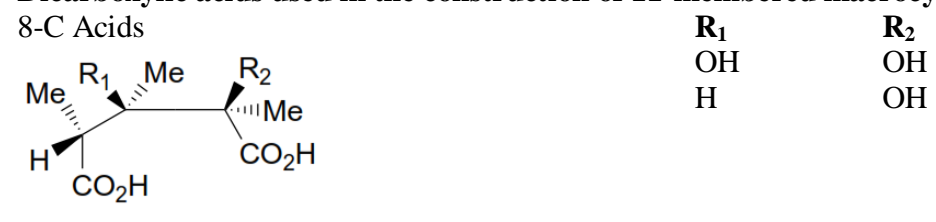

Monocrotalic acid

Crotaleschenic acid

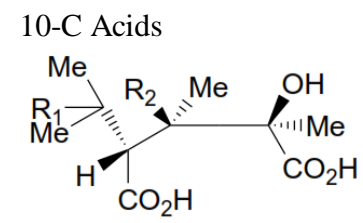

$\begin{array}{ll}\mathbf{R}_{\mathbf{1}} & \mathbf{R}_{\mathbf{2}} \\ \mathrm{H} & \mathrm{H} \\ \mathrm{H} & \mathrm{OH} \\ \mathrm{OH} & \mathrm{OH}\end{array}$

Incanic acid

Trichodesmic acid

Globiferic acid 
Comfrey, a Latin word for "growing together," is a member of the plant family Boraginaceae (Raymond 1997; Squires 2010). Several plant species in the genus Symphytum belong to the group of comfrey, such as wild or common comfrey and S. officianale L., which is native to England and extends throughout most of Europe and Asia, and western Siberia. Others are prickly or rough comfrey (S. asperum L.), named for its bristly or hairy leaves, brought to Britain from Russia in about 1800. Quaker, Russian or blue comfrey (S. uplandicum N.), originated as a natural hybrid of $\mathrm{S}$. officianale and $S$. asperum. This hybrid was called Russian or Caucasian comfrey in reference to its country of origin (Teynor et al. 1992). More known comfrey include: S. bulbosum Shimp, Bulbous Comfrey, S. caucasicum Bieb, Caucasian Comfrey, $S$. ibericum Steven, Creeping Comfrey, S. orientale, White Comfrey, S. tauricum, Crimean Comfrey, S. tuberosum, Tuberous Comfrey, (S. asperum $x$ officinale, synonym: $S$. peregrinum) (Kartal et al. 2001; Mei et al. 2010), $S$. sylvaticum, $S$. aintabicum (Kurucu et al. 2001), $S$. asperrimum, S. cordatum, and $S$. grandiflorum (Squires 2010).

The major constituents found in the comfrey plant include allantoin, mucilage, amino acids, PAs (Teynor et al. 1992; Raymond 1997; Squires 2010), proteins, vitamins $\mathrm{B}_{12}$ (Teynor et al. 1992; Squires 2010), tannins, phytosterols, triterpenoids, polyphenols (Raymond 1997; Squires 2010). Other constituents include mucopolysaccharides (Neagu et al. 2010), coniferin, carotene, starch, mineral substances $(\mathrm{Ca}, \mathrm{K}, \mathrm{P}, \mathrm{Mg}, \mathrm{Fe}, \mathrm{Mn}$, $\mathrm{Na}, \mathrm{Zn}$ ) (Neagu et al. 2011), phenolic acids (rosmarinic, chlorogenic, caffeic and lithospermic), choline, asparagines, volatile oil, steroidal saponins (Squires 2010).

The objectives of this study were (i) To isolate and characterize the various types of PAs in leaves and roots of $S$. asperum collected from distinct parts of Kiambu and Kisii Counties using GC-MS. (ii) To determine the concentrations of PAs in the S. asperum obtained from different parts of Kiambu and Kisii counties during two seasons, wet and dry, throughout the year.

\section{MATERIALS AND METHODS}

\section{Study area}

The study was performed in the selected areas of Kiambu County (Githunguri, Kahawa, and Ruiru) and Kisii County (Kenyenya sub-County) of Kenya, where these plants are widely grown and used.

\section{Sample collection and sample size}

Samples were collected from the roots and leaves of comfrey grown at selected locations in Kiambu County and parts of Kisii during the wet (April 2012) and dry (September 2012) seasons of the year. Large leaves that were ready for consumption are preferable for this study. The samples were obtained from small-scale farmers who largely depended on the crop as a vegetable. A taxonomist from Kenyatta University verified the plant's identity. A sample specimen SO/SA/2012/1 was deposited in the university herbarium. The sample collection locations varied from close to water points (streams or near water taps) to behind kitchens at the farmer's homestead.

\section{Sample preparation and extraction of PAs}

Samples were air-dried at ambient temperature (Crews et al. 2009) and ground into fine powders for four weeks. From six selected locations, a total of twenty-four samples of roots and leaves were collected during the wet season and the dry season. Thirty grams of either ground roots or ground leaves were placed in a conical flask and added with $100 \mathrm{ml}$ of chloroform/methanol (85:15) and $5 \mathrm{ml}$ of ammonium hydroxide ( $25 \%$ solution). The mixture was extracted mechanically using a shaking water bath at room temperature for 90 minutes. The extraction process was followed by filtration and reaction with $30 \mathrm{ml} 2 \mathrm{M} \mathrm{HCl}$ to allow separation of the two-phase solution, the organic layers, and the aqueous layers. A separating funnel separated both layers, and the aqueous layer was neutralized with sodium carbonate and further extracted with chloroform $(25 \mathrm{ml} \times 3)$. The mixed chloroform extract was dried over anhydrous sodium sulfate and filtered. A portion of the filtrate was spotted on the TLC plate and eluted with a solvent mixture of chloroform: methanol. To visualize the presence of candidate PAs, the plate was then sprayed with Draggendorf reagent. The remaining filtrate was then concentrated in the rotary evaporator, and as many as $\sim 1-2 \mathrm{ml}$ were transferred into a glass pre-weighed vial. To remove the residual organic solvent, the filtrate was gently flushed with a stream of nitrogen gas. Finally, the weight of the blend of PA alkaloids was recorded, and then continued with the extract's analysis by using GC-MS. This procedure was repeated for all twenty-four samples (Wuilloud et al. 2004).

\section{Gas Chromatography linked with Mass Spectrometer}

The composition of the alkaloid extracts was determined using a gas chromatograph system (GC 8000 series) with a fused capillary column (15 m length; 0.25 $\mathrm{mm}$ i. d.; $0.25 \mu \mathrm{m}$ film thickness; static phase methyl silicone SE-30) directly coupled to a quadrupole mass spectrometer (Hewlett Packard 5973). Electron impact ionization was performed at an energy of $70 \mathrm{eV}$. Helium was used as a carrier gas injector, and the detector was maintained at $200^{\circ} \mathrm{C}$ and $250^{\circ} \mathrm{C}$, respectively. The analytical conditions were as follows: oven temperature was $2 \mathrm{~min}$ isothermal at $60^{\circ} \mathrm{C}$, then 60 to $240^{\circ} \mathrm{C}$ at a rate of $15^{\circ} \mathrm{C} / \mathrm{min}$, then held isothermal for $6 \mathrm{~min}$. The instrument was scanned at a mass range from 60 to $400 \mathrm{amu}$.

The blank solution of Dichloromethane (DCM) was run in the GC-MS, and its TIC (Total Ion Chromatogram) and its mass spectrum were obtained. Methyl stearate (10 ppm) was prepared in DCM and run in the GC-MS equipment to obtain the TIC and the mass spectrum. The extract in the vials was resuspended in methyl stearate $(10 \mathrm{ppm})$, then combined and shaken with $0.5 \mathrm{ml}$ of methyl stearate to entirely dissolve the extract. One microliter of the dissolved extract was injected into the GC-MS equipment. For each sample, two injections were done. GC-MS were set to the Tundis et al. (2006) protocol conditions. By 
comparing mass spectral data on computer and NIST library and reviewing the literature mass-spectral fragmentation data, the candidate of the alkaloids can be identified. The total ion chromatograms and their corresponding mass spectra are given in Figures S1 to S10 (Appendix). The data obtained were analyzed using a t-test at a $95 \%$ confidence limit.

\section{RESULTS AND DISCUSSION}

The percentage weight of the pooled solvent extracts for the roots and the leaves during wet and dry seasons is displayed in Table 2. The t-test means the percentage of dry weight is given in Table 3 .

The results showed no significant difference in the dry weight of leaves and root extracts between the wet and dry seasons ( $>0.05$ at $95 \%$ confidence limit). However, there were significant differences in the dry weight extracts of the roots and leaves in both seasons $(p<0.05$ at $95 \%$ confidence level).

In both seasons, the weight of the root extracts was more than the weight of the leaf extracts. There were mixed results for the weights measured from the root extracts between the wet and dry seasons, whereby three locations (Kiamumbi (ZW), Ruiru (RR), and Githunguri (GB)) recorded higher weights during the wet season compared to the counterpart data of the dry season. Meanwhile, the other three sampling locations (Kahawa Sukari (KW), Kisii $(\mathrm{KS})$, and Kiambu (KB)) recorded higher weights during the dry season.

Table 2. Percentage weight of dried extracts from dried leaves and roots, respectively, obtained during the wet and dry seasons obtained from Kisii and Kiambu, Kenya

\begin{tabular}{lllllll}
\hline Masses (\%) & KW & ZW & RR & KS & KB & GR \\
\hline Leaves wet season & 0.069 & 0.047 & 0.020 & 0.015 & 0.009 & 0.012 \\
Roots wet season & 0.059 & 0.104 & 0.072 & 0.063 & 0.159 & 0.114 \\
Leaves dry season & 0.037 & 0.031 & 0.041 & 0.049 & 0.023 & 0.060 \\
Roots dry season & 0.164 & 0.096 & 0.062 & 0.159 & 0.203 & 0.045
\end{tabular}

Note: KB: Kiambu, KW: Kahawa Sukari, KS: Kisii, ZW: Kiamumbi, GR: Githunguri, RR: Ruiru

Table 3. The mean $( \pm \mathrm{SE})$ percentage dry weight of the roots and leaves during the dry and wet seasons

\begin{tabular}{lccc}
\hline Part & $\begin{array}{c}\text { Wet } \\
(\text { Mean } \pm \text { SE) }\end{array}$ & $\begin{array}{c}\text { Dry } \\
(\text { Mean } \pm \text { SE })\end{array}$ & p-values \\
\hline Roots & $0.10 \pm 0.02$ & $0.12 \pm 0.03$ & 0.403 \\
Leaves & $0.03 \pm 0.01$ & $0.04 \pm 0.01$ & 0.328 \\
p-value & 0.005 & 0.024 & \\
\hline
\end{tabular}

For the leaf extracts, a higher dry weight in the wet season was recorded in Kahawa Sukari (KW) and Kiamumbi (ZW), while the rest recorded higher weights during the dry season than in the wet season. Therefore, the variation in weights of the samples between the two seasons suggests it did not follow a particular pattern. The variation is perhaps attributed to the differences in the maturity of the leaves collected for analyses, the leaf size, and the lifespan (age) of the plant. Where possible, larger leaves were used in this study regarding their size. Both leaf and root samples were taken in April 2012 (wet season) and September 2012 (dry season).

These plants seemed not to be physiologically affected by a lack of water supply during the dry season. They grew near water points or behind the kitchen, where regular access to water was available. Similarly, the sampling regions did not experience adverse effects due to the dry spells. The rainfall intensity in these regions would be minimal, occasional during the dry season. Thus, the plants would not, therefore, be said to lack water. This would also explain the variability of the weights between the wet and dry seasons.

TLC of concentrated root and leaf extracts sprayed with Dragendorff reagent exhibited brown-orange spots, indicating the presence of alkaloids (Eyad 2007). The GCMS presenting the total ion chromatograms and their corresponding mass spectra are provided in Figures S1 to S10.

The total ion chromatogram for the root samples obtained from Kiambu during the wet season is given in Figure 1 for illustration purposes.

Based on TIC data, a total of three PAs (Table 4), namely echimidine (7), 3-Acetyllycopsamine (18), and heliosupine (24), were all identified from the database from the NIST library. The compound 7-Acetyllycopsamine (17) was identified from the mass spectral fragmentation data since the NIST library could only give the spectra but no identity. The mass spectra of the PAs identified in this study are shown in Figures 2 to 5.

Three compounds detected had characteristic ions at $\mathrm{m} / \mathrm{z}$ 55, 80, 93, 94, 120, 136 and 220 (echimidine and heliosupine), at $m / z 55,80,93,94,120,136,138$ and 220 (3-acetyllycopsamine), and at $m / z$ 55, 80, 93, 94, 120, 138, 180 and 220 (7-acetyllycopsamine). They all showed intense ions at $\mathrm{m} / \mathrm{z}$ 93, 120, 136, and 220. Furthermore, 7acetyllycopsamine showed an intense ion at $\mathrm{m} / z$ 180. These characteristics are typical of unsaturated PAs (Witte et al. 1992; Wuilloud 2004; Tundis et al. 2006; Rosemann 2006; Crews et al. 2009). The proposed structures of these fragment ions are given in Figure 6.

Table 4. PAs were obtained from root samples from Kiambu, Kenya, during the wet season

\begin{tabular}{ll}
\hline Retention time & Pyrrolizidine alkaloid \\
\hline 13.46 & 3-Acetyllycopsamine (18) \\
13.68 & 7-Acetyllycopsamine (17) \\
15.56 & Echimidine (7) \\
15.73 & Heliosupine (24) \\
\hline
\end{tabular}




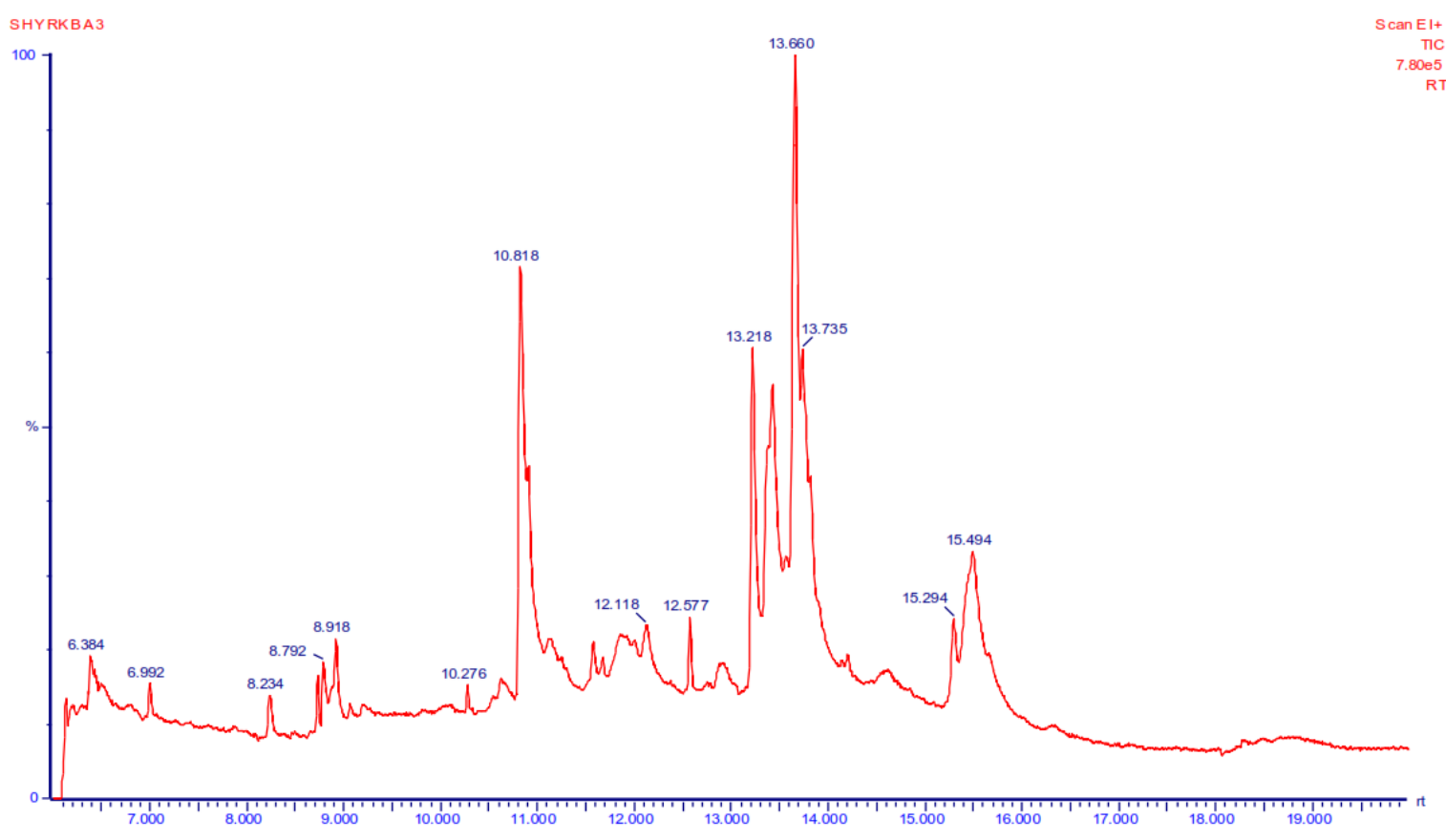

Figure 1. TIC of the sample collected from Kiambu, Kenya, during the wet season

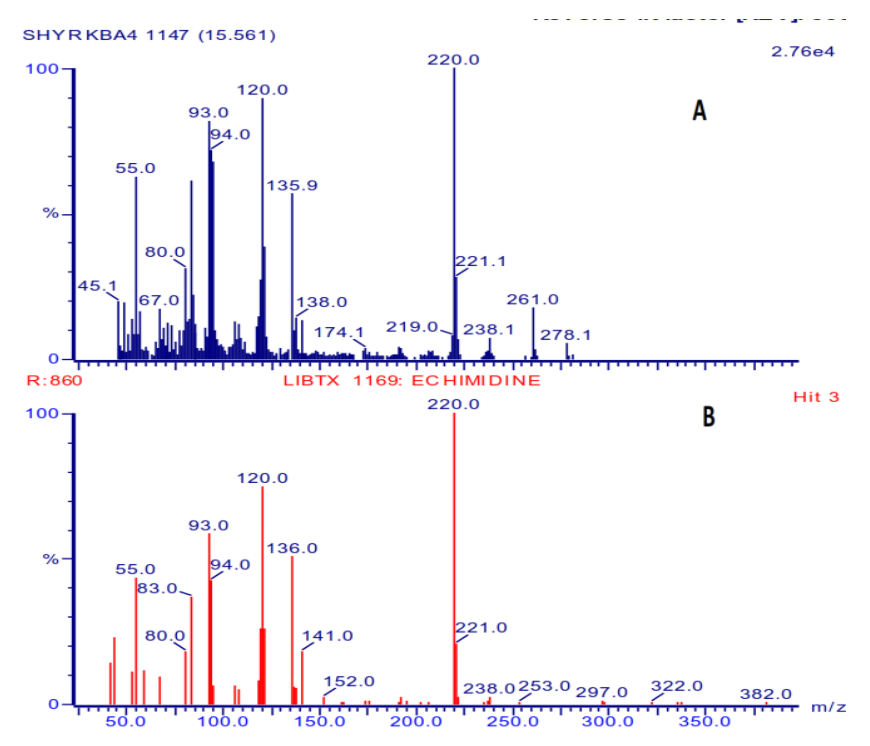

Figure 2. The mass spectra of echimidine (7) in a sample collected from Kiambu, Kenya, during the wet season (A: Sample spectrum, B: NIST Library spectrum)

The fragmentation pattern of echimidine, whose characteristic ions are at $\mathrm{m} / \mathrm{z} 55,80,93,94,120,136$, and 220. is shown below in Figure 7.

GC-MS analyses were done for all of the root and leaf samples. None of the leaf samples showed a positive test for the PAs. In contrast, the root samples gave a positive result for the PAs. The TICs and mass spectra of the whole root samples are presented in Figures $\mathrm{S} 1$ to $\mathrm{S} 10$. Identification of the pyrrolizidine alkaloids was determined regarding their mass spectra compared to the mass spectra published by the NIST library. In some cases (7-

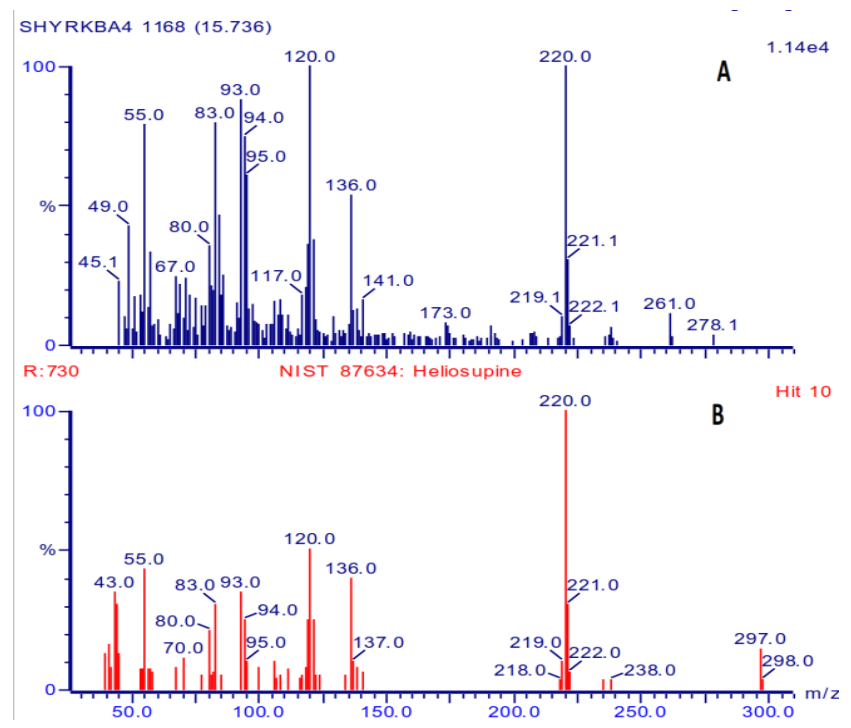

Figure 3. The mass spectra of heliosupine (24) in a sample collected from Kiambu, Kenya, during the wet season (A: sample spectrum, B: NIST library spectrum)

acetyllycopsamine in particular), identification was made from mass spectral fragmentation patterns by referring to the literature data because the NIST library did not provide identity information. The concentrations of each alkaloid were measured from their peak area ratios and compared to the peak area ratio of methyl stearate as the internal standard. The concentration of the internal standard has been determined. A summary of the PAs identified and their corresponding concentrations are presented in Table 5 . 


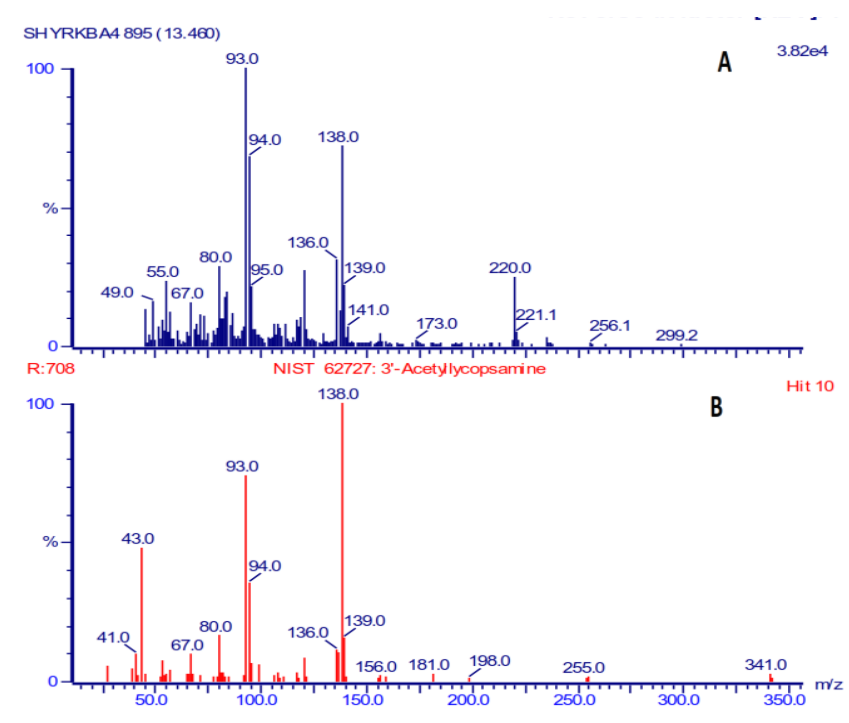

Figure 4. The mass spectra of $3^{\text {' }}$-acetyllycopsamine (18) in a sample collected from Kiambu, Kenya, during the wet season (A: sample spectrum, B: NIST library spectrum)

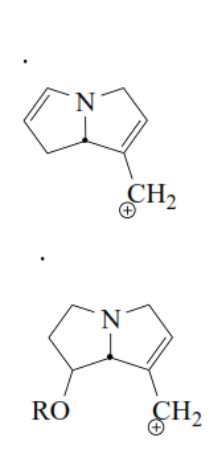

$\mathrm{R}$

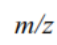

120

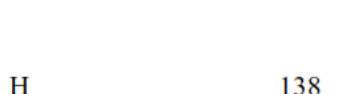

$\mathrm{H}$

138

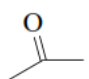

180

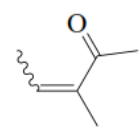

220

$\mathrm{H}$

156<smiles>[R20]C1CCN2CC=C(CO)C12</smiles><smiles>CC(C)=O</smiles><smiles>CC=C(C)C(C)=O</smiles>

238

$\mathrm{H}$<smiles>[R20]C1CC[Y]2([H])CC=C(COC(=O)C(O)C(C)C)C12</smiles>

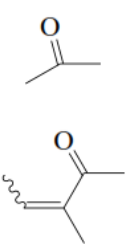

298

338

Figure 6. Proposed structures of fragment ions observed in the mass spectra of PAs (Witte et al. 1992; Wuilloud 2004; Tundis et al. 2006 and Rosemann 2006)

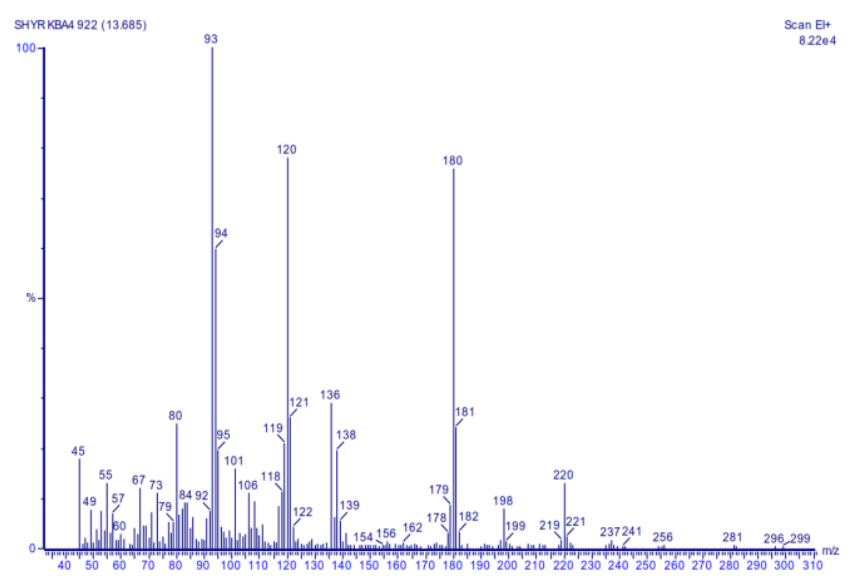

Figure 5. The mass spectra of 7-acetyllycopsamine (17) in the root sample collected from Kiambu, Kenya, during the wet season (Culvenor et al. 1980; Wuilloud et al. 2004)
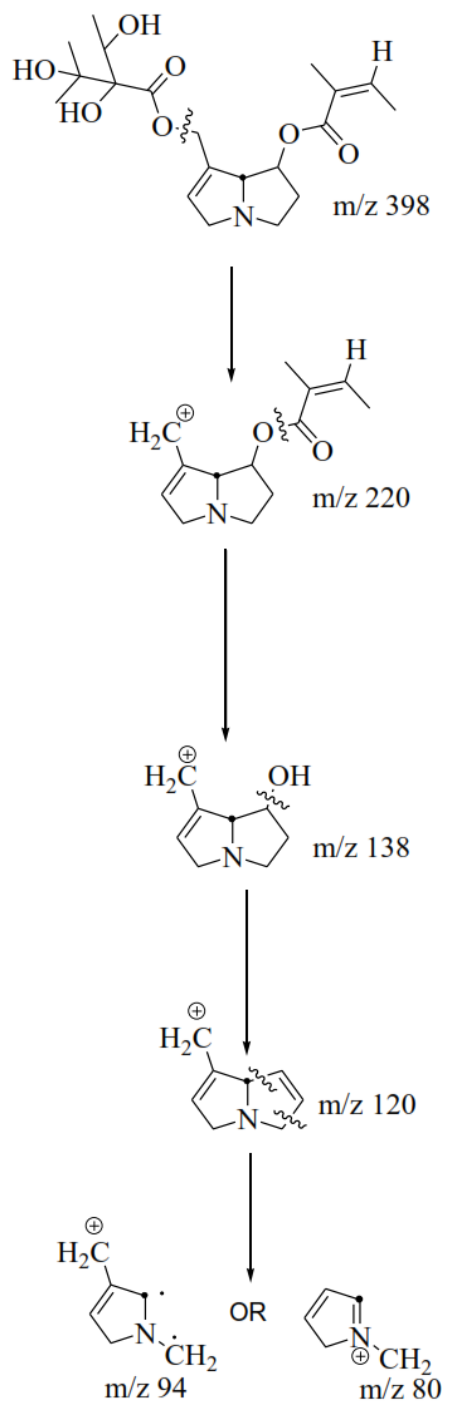

Figure 7. Proposed fragmentation pattern for echimidine (Rosemann 2006) 
Echimidine (7) was found in the root samples in all sampling locations. At the same time, Heliosupine (24) was also detected from all locations except in Kiambu during the dry season and in Githunguri during the wet season. Other PAs identified were 7-acetyllycopsamine (17), 3acetyllycopsamine (18), and triangularine (19). The concentration of the PAs (in ppm) ranged from $2 \mathrm{ppm}$ to $10 \mathrm{ppm}$. The PAs were, however, below detectable levels in the leaf samples.

Some of the PAs reported in the Symphytum spp include echimidine (7), lycopsamine (11) and 7-acetyllycopsamine (17) (Awang et al. 1993; Culvenor et al. 1980), symphytine (8), 7-acetylintermedine (10), Symviridine (12), triangularine (19), uplandicine (20), symlandine (21), myoscorpine (22), echiumine (23) (Wuilloud et al. 2004; Culvenor 1983, Mei et al. 2010; WHO 1988), heliosupine (24) and asperumine (25) (Wuilloud et al. 2004). All these PAs are unsaturated and of retronecine type. Five of these PAs, echimidine (7), 7-acetyllycopsamine (17), (3-Acetyllycopsamine (18), triangularine (19), and heliosupine (24), were identified from the analyzed root samples.

Depending on the plant region, the PAs level varies, with the roots having the highest concentrations, followed by the small leaves. Previous studies indicate that mature leaves have the lowest concentrations (Culvenor et al., 1980; Mattocks, 1980; Awang et al., 1993; Betz et al., 1994; Fu et al., 2001; Oberlies et al., 2004; Mei et al., 2010; McCall and Fordyce 2010). Oberlies et al. (2004) note that the leaves of $S$. $x$ uplandicum had a 16-fold higher concentration of total PAs in small leaves than in large leaves. On the other hand, a complete lack of PAs in the leaves of S. officinale has been reported (Betz et al. 1994), indicative of natural biological (epigenetic or chemotypic) variations associated with local environmental differences (Betz et al. 1994), as well as precise the age of the plant material (Mei et al. 2010). In the present study, undetectable amounts of PAs in the leaf samples could be attributed to similar factors. A more detailed investigation of the levels of the PAs in leaves of different sizes and different ages plants growing in different seasons under different conditions would help shed further light on this question.

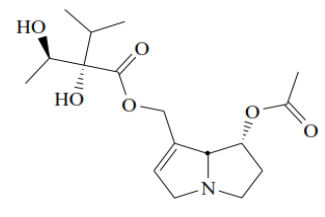

(17)

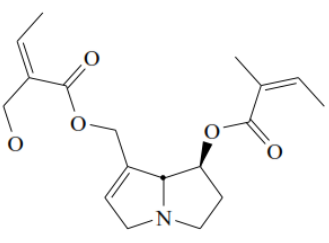

(19)

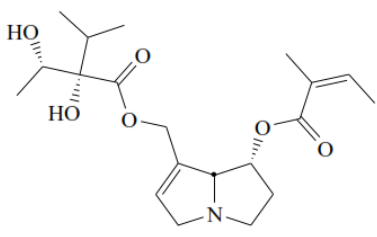

(21)

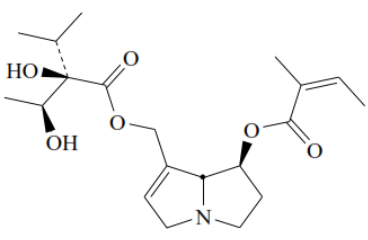

(23)

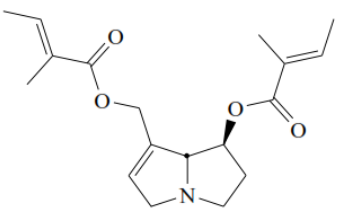

(25)

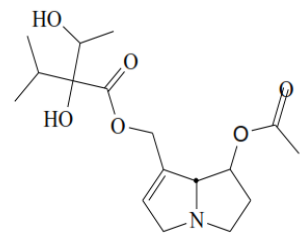

(18)

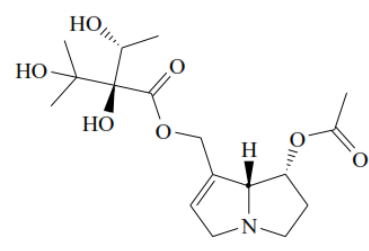

(20)

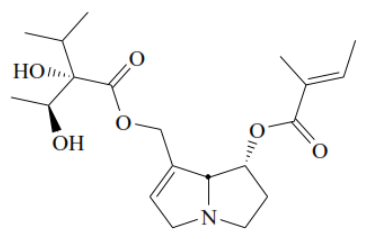

(22)

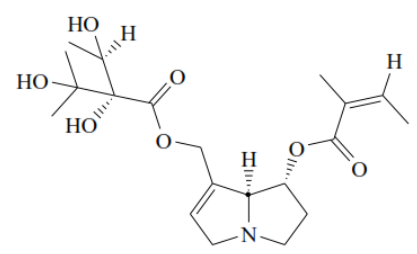

(24)

Table 5. PA types and means levels (ppm) in the roots from Kiambu and Kisii counties of Kenya

\begin{tabular}{|c|c|c|c|c|c|c|}
\hline Location & Season & $\begin{array}{l}\text { Echimidine } \\
(\text { mean } \pm \text { SD })\end{array}$ & $\begin{array}{c}\text { Heliosupine } \\
(\text { mean } \pm \text { SD) }\end{array}$ & $\begin{array}{c}\text { 7-Acetyllycopsamine } \\
(\text { mean } \pm \text { SD })\end{array}$ & $\begin{array}{c}\text { 3-Acetyllycopsamine } \\
(\text { mean } \pm \text { SD })\end{array}$ & $\begin{array}{c}\text { Triangularine } \\
(\text { mean } \pm \text { SD })\end{array}$ \\
\hline \multirow[t]{2}{*}{$\overline{\mathrm{KB}}$} & Wet & $4.26 \pm 0.07$ & $3.36 \pm 0.05$ & $9.46 \pm 0.08$ & $6.54 \pm 0.05$ & - \\
\hline & Dry & $4.23 \pm 0.06$ & - & $5.51 \pm 0.05$ & - & $6.95 \pm 0.11$ \\
\hline \multirow[t]{2}{*}{ KW } & Wet & $2.25 \pm 0.13$ & $3.32 \pm 0.09$ & $8.04 \pm 0.08$ & $4.54 \pm 0.07$ & - \\
\hline & Dry & $2.54 \pm 0.08$ & $2.45 \pm 0.08$ & $2.14 \pm 0.07$ & - & $2.53 \pm 0.12$ \\
\hline \multirow[t]{2}{*}{$\mathrm{KS}$} & Wet & $7.53 \pm 0.11$ & $9.1 \pm 0.04$ & $8.37 \pm 0.05$ & - & - \\
\hline & Dry & $4.27 \pm 0.04$ & $2.53 \pm 0.07$ & - & $3.44 \pm 0.08$ & - \\
\hline \multirow[t]{2}{*}{$\mathrm{ZW}$} & Wet & $3.32 \pm 0.09$ & $3.20 \pm 0.06$ & - & $8.52 \pm 0.11$ & - \\
\hline & Dry & $2.55 \pm 0.10$ & $3.53 \pm 0.17$ & - & - & - \\
\hline \multirow[t]{2}{*}{ GR } & Wet & $2.28 \pm 0.12$ & - & $3.54 \pm 0.08$ & - & $2.59 \pm 0.10$ \\
\hline & Dry & $4,17 \pm 0.04$ & $5.56 \pm 0.12$ & - & $10.57 \pm 0.11$ & $5.29 \pm 0.03$ \\
\hline \multirow[t]{2}{*}{ RR } & Wet & $2.41 \pm 0.04$ & $2.44 \pm 0.11$ & $3.50 \pm 0.08$ & - & $4.64 \pm 0.15$ \\
\hline & Dry & $3.54 \pm 0.07$ & $3.54 \pm 0.12$ & $4.58 \pm 0.20$ & - & $7.24 \pm 0.12$ \\
\hline
\end{tabular}


Table 6. The pyrrolizidine alkaloids' mean $( \pm \mathrm{SE})$ concentration (ppm) was obtained from the roots during the wet and dry seasons

\begin{tabular}{lcccc}
\hline $\begin{array}{l}\text { Pyrrolizidine } \\
\text { alkaloids }\end{array}$ & n & $\begin{array}{c}\text { Dry } \\
(\mathbf{M e a n} \pm \text { SE) } \\
\mathbf{p p m}\end{array}$ & $\begin{array}{c}\text { Wet } \\
\left(\begin{array}{c}\text { Mean } \pm \text { SE) } \\
\mathbf{p p m}\end{array}\right.\end{array}$ & p-value \\
\hline Echimidine & 12 & $3.55 \pm 0.23$ & $3.67 \pm 0.56$ & 0.841 \\
Heliosupine & 10 & $3.52 \pm 0.38$ & $4.27 \pm 0.80$ & 0.408 \\
7-Acetyllycopsamine & 6 & $4.08 \pm 0.64$ & $6.58 \pm 0.85$ & 0.033 \\
3-Acetyllycopsamine & 4 & $7.00 \pm 2.06$ & $6.53 \pm 0.73$ & 0.840 \\
Triangularine & 8 & $5.50 \pm 0.71$ & $3.61 \pm 0.60$ & 0.070 \\
\hline
\end{tabular}

A t-test was done on the PA identified between the wet and dry seasons, and the results are shown in Table 6.

The level of 7-Acetyllycopsamine was significantly higher during the wet season than during the dry season $(p=0.033, \alpha=0.05, t$-test $)$. The other pyrrolizidine alkaloids did not vary considerably between the dry and wet seasons ( $\mathrm{p}>0.05, \alpha=0.05$, t-test).

\section{Conclusions}

GC-MS analyses of all the root samples detected a total of 5 PAs, in which Echimidine (7) was found in all of the root samples analyzed. Meanwhile, 7-Acetyllycopsamine (17), 3-acetyllycopsamine (18), and triangularine (19) were found only in some root samples. This variation might be attributed to differences in the age of the plant and epigenetic/chemotypic differences resulting from changes in soil and other environmental conditions in areas from where the plants were harvested (Betz et al. 1994; Mei et al. 2010). Heliosupine, which is the other PA identified in the roots of all extracts in the study, is a stereoisomer of Echimidine. Its toxicity is yet to be studied. No detectable levels of PAs were found in the leaf samples of S. asperum collected from any of the locations in both seasons. A previous study on $S$. officinale leaves described the total absence of PAs (Betz et al. 1994). However, other studies reported varying levels of PAs in the leaves, with the highest levels being in the small, young leaves, especially early in the season (Mattocks 1980). Oberlies et al. (2004) reported a 16-fold higher concentration of total PAs in small leaves than in large ones. In this study, larger mature leaves were mostly used since they were consumed.

\section{REFERENCES}

ANZFA [Australia New Zealand Food Authority]. 2001. Pyrrolizidine alkaloids in food-A toxicological review and risk assessment. Technical Report Series No.2. Australia New Zealand Food Authority, Canberra, and Wellington.

Awang DVC, Dawson BA, Fillion J, Girad M, Kindack D. 1993. Echimidine content of commercial comfrey (Symphytum spp. Boraginaceae). J Herbs, Spices Med Pl 2: 21 - 34.

Betz JM, Eppley RM, Taylor WC, Andrezejewski D. 1994. Determination of pyrrolizidine alkaloids in commercial comfrey products (Symphytum sp). J Pharmaceut Sci 83 (5): 649-653.

Boppré M. 2011. The ecological context of pyrrolizidine alkaloids in food, feed, and forage: an overview. Food Addit Contam 28: 260-281.

CODEX, Joint FAO/WHO Food Standards Programme Codex Committee On Contaminants in Foods. 2011. Discussion Paper On Pyrrolizidine Alkaloids. CX/CF 11/5/14.
COT [Committee on Toxicity]. 2008. Committee on toxicity of chemicals in food, consumer products, and the environment, COT Statement on Pyrrolizidine Alkaloids in Food, Food Standard Agency, UK.

Coulombe RA. 2003. Pyrrolizidine alkaloids in foods. Adv Food Nutr Res 45: 61-98.

Crews C, Berthiller F, Krska R. 2009.Update on analytical methods for toxic pyrrolizidine alkaloids. Anal Bioanal Chem 396: 327-338.

Culvenor CCJ, Edgar JA, Frahn JL, Smith LW. 1980. The Alkaloids of Symphytum x uplandicum (Russian Comfrey). Austr J Chem 33: 1105-1113.

Culvenor CCJ. 1983. Estimated intakes of pyrrolizidine alkaloids by humans. A comparison with dose rates causing tumors in rats. $\mathrm{J}$ Toxicol Environ Health 11: 625-635.

Eyad SI. 2007. Isolation and characterization of pyrrolizidine alkaloids from Echium glomeratum poir (Boraginaceae). [Thesis]. Jordan University of Science and Technology, Amman.

FAO [Food and Agriculture Organization]. 2010. Pyrrolizidine alkaloids in foods and animal feeds. FAO Consumer Protection Fact Sheets No. 2: 1-6.

Fu PP, Chou MW, Xia Q, Yang Y.C, Yan J, Doerge DR, Chan PC. 2001. Genotoxic pyrrolizidine alkaloids and pyrrolizidine alkaloid $N$ oxides-mechanisms leading to DNA adduct formation and tumorigenicity. Environ Carcinogen Ecotoxicol Rev 19: 353-385.

Fu PP, Xia Q, Lin G, Chou MW. 2004. Pyrrolizidine alkaloids-genotoxicity, metabolism enzymes, metabolic activation, and mechanisms. Drug Metabol Rev 36 (1): 1-55.

Fu PP, Yang Y-C, Xia Q, Chou MW, Cui YY, Lin G. 2002. Pyrrolizidine alkaloids-tumorigenic components in Chinese herbal medicines and dietary supplements. J Food Drug Anal 10 (4): 198-211.

Kartal M, Kurucu M, Choudary I. 2001. Antifungal activities of different extracts and echimidine-N-oxide from Symphytum sylvaticum Boiss. subsp. sepulcrale (Boiss. \& Bal.) Greuter \& Burdet var. Sepulcrale. Turkish J Med Sci 31: 487-492.

Kurucu S, Kartal M, Choudary MI, Topcu G. 2001. Pyrrolizidine Alkaloids from Symphytum sylvaticum Boiss. subsp. sepulcrale. (Boiss. \& Bal.) Greuter \& Burdet var. sepulcrale and Symphytum aintabicum. Turkish J Chem 26: 95-99.

Mattocks AR. 1980. Toxic pyrrolizidine alkaloids in comfrey. Lancet 29: 1136-1137.

McCall AC, Fordyce JA. 2010. Can optimal defence theory be used to predict the distribution of plant chemical defences? J Ecol 98 (5): 985-992.

Mei N, Guo L, Fu PP, Fuscoe JC, Luan Y, Chen T. 2010. Metabolism, genotoxicity, and carcinogenicity of comfrey. J Toxicol Environ Health Part B 13: 509-526.

Molyneux RJ, Johnson AE, Olsen JD, Baker DC. 1991. Toxicity of pyrrolizidine alkaloids from Riddell's groundsel. Amer J Vet Res 52: 146-151.

Neagu E, Păun G, Radu LG. 2011. Phytochemical study of some Symphytum officinalis extracts concentrated by membranous procedures, Sci Bull-University Politechnica Buchacharest Series B 73: 3-7.

Neagu E, Roman GP, Radu GL. 2010. Antioxidant capacity of some Symphytum officinalis extracts processed by ultrafiltration. Romanian Biotechnol Lett 15 (4): 5505-5511.

Oberlies NH, Kim NC, Brine DR, Collins BJ, Handy RW, Sparacino CM, Wani MC, Wall ME. 2004. Analysis of herbal teas made from the leaves of comfrey (Symphytum officinale): reduction of $\mathrm{N}$-oxides results in order of magnitude increases in the measurable concentration of pyrrolizidine alkaloids. Public Health Nutr 7: 19-24.

Pawar R, Grundel E, Mazzola E, White K, Krynitsky AJ, Rader JI. 2010. Chiral stationary phases for separation of intermedine and lycopsamine enantiomers from Symphytum uplandicum. J Separation Sci 33: 200-205.

Raymond T. 1997. Comfrey and one of its constituent alkaloid, symphytine; Review of Toxicological Literature. Research Triangle Park, North Carolina 27709. 1-7.

Roeder E. 1999. Analysis of pyrrolizidine alkaloids. Curr Org Chem 3: 557-576.

Rosemann GM. 2006. Analysis of pyrrolizidine alkaloids in Crotalaria species by HPLC-MS/MS in order to evaluate related food health risks. University of Pretoria, Pretoria, South Africa.

Squires MJ. 2010. US Patent Application 20100303935-Medicinal Composition.

Teynor TM, Putnam DH, Doll JD, Kelling KA, Oelke EA, Undersander DJ, Oplinger ES. 1992. Comfrey. Department of Agronomy and Plant 
Genetics, Minnesota Extension Service University of Minnesota, St. Paul, USA.

Tundis R, Monica RL, Giancarlo AS, Nicodemo GP, Lorenzo P, Francesco M. 2006. Pyrrolizidine alkaloid profiles of the Senecio cineraria group (Asteraceae). Biochem Syst Ecol 33: 1071-1076.

WHO. 1988. International program on chemical safety, pyrrolizidine alkaloids. Environmental Health Criteria 80, Finland.
Witte L, Ernst L, Adam H, Hartmann T. 1992. Chemotypes of 2 pyrrolizidine alkaloid-containing Senecio species. Phytochem Rev 31: 559-565.

Wuilloud CA, Gratz SR, Gamble BM, Wolnik KA. 2004. Simultaneous analysis of hepatotoxic pyrrolizidine alkaloids and $N$-oxides in comfrey root by LC-ion trap mass spectrometry US Food and Drug Administration, Forensic Chemistry Center, Cincinnati, Ohio 452373097, USA. Analyst 129: 150-156. 

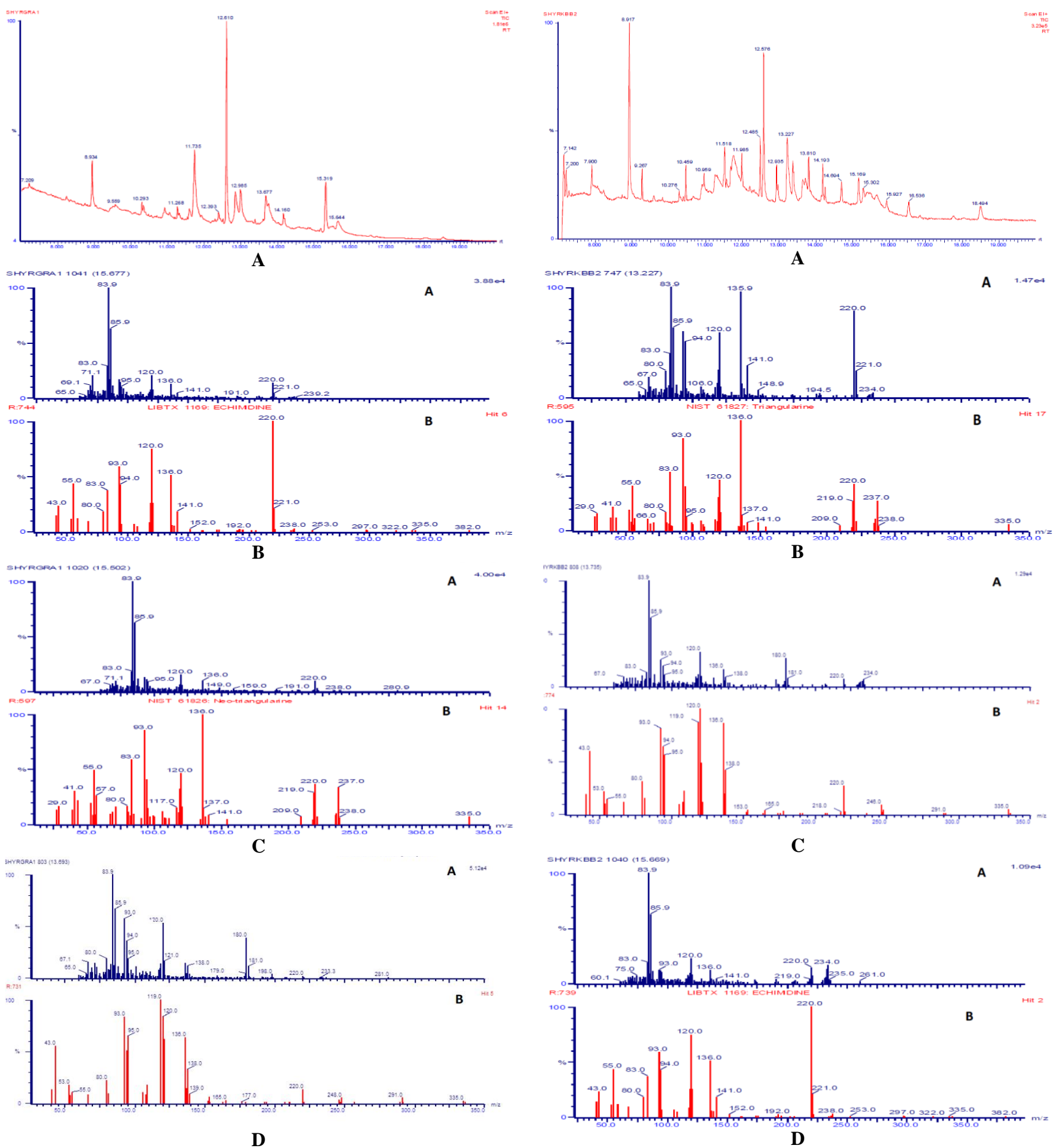

Figure S1.A. TIC of the sample collected from Githunguri, wet season. B. Mass spectra of echimidine in the sample collected from Githunguri, wet season. C. Mass spectra of triangularine in the sample collected from Githunguri, wet season. D. Mass spectra of 7-acetyllycopsamine in the sample collected from Githunguri, wet season. Note for Figure S1 to S10, Above/A: sample spectrum, Below/B: NIST library spectrum)

Figure S2.A. TIC of the sample collected from Kiambu, dry season. B. Mass spectra of triangularine in the sample collected from Kiambu, dry season. C. Mass spectra of 7acetyllycopsamine in the sample collected from Kiambu, dry season. D. Mass spectra of echimidine in the sample collected from Kiambu, dry season 


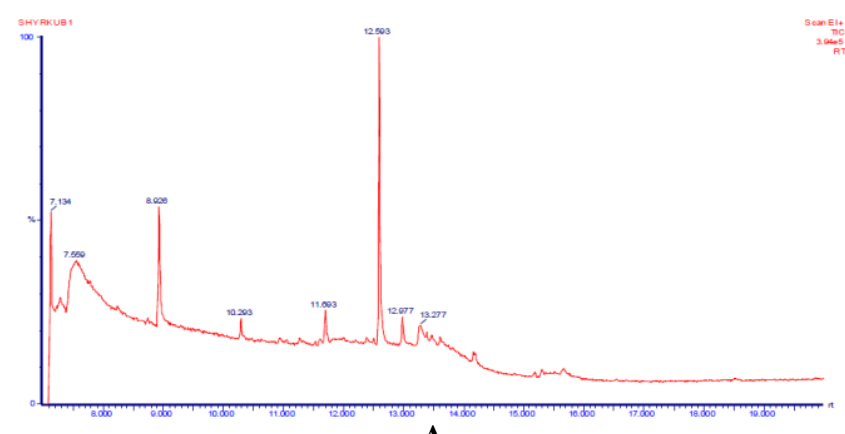

A
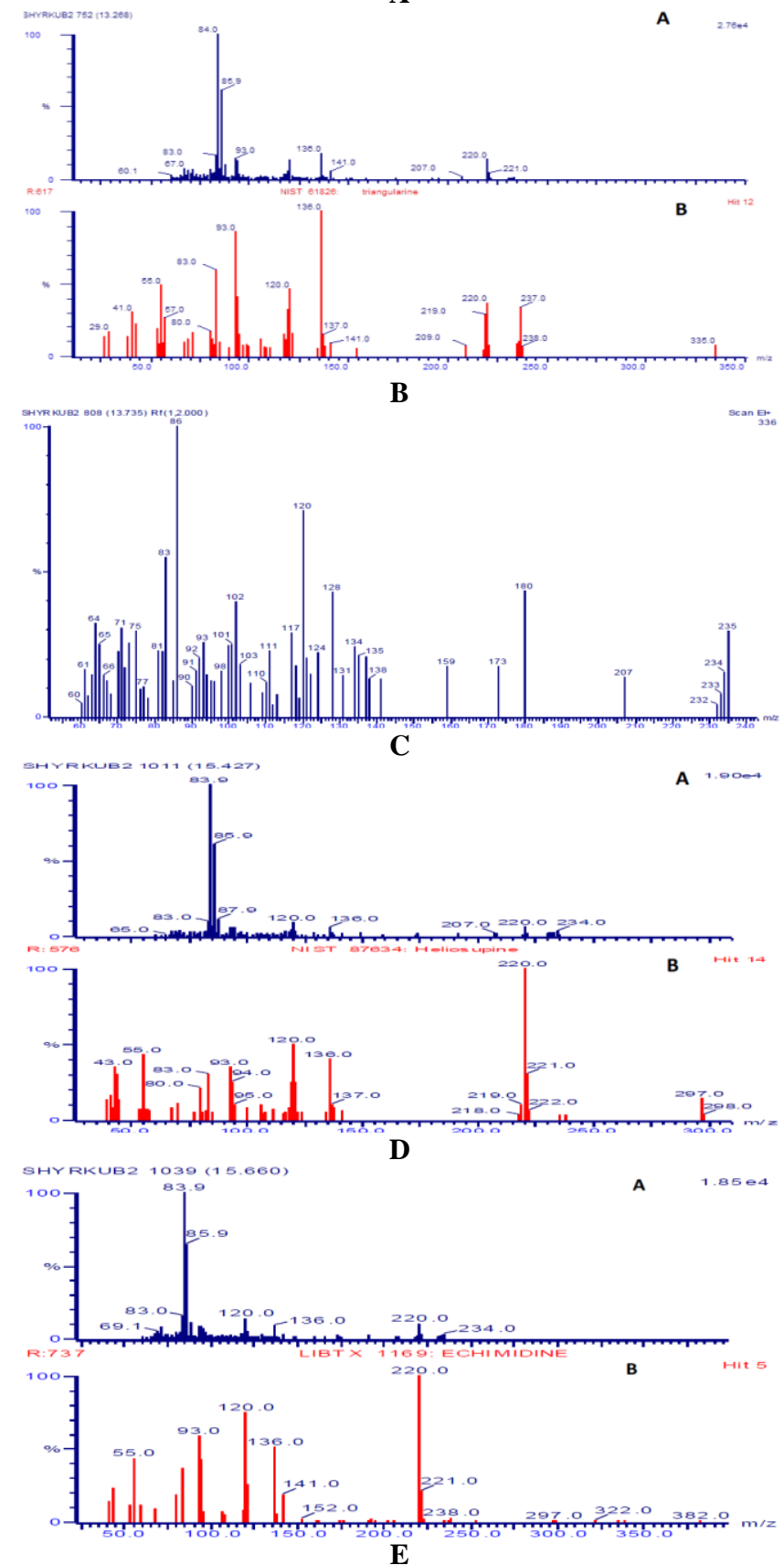

$\mathbf{E}$

Figure S3 .A. TIC of the sample collected from Kahawa Sukari, dry season. B. Mass spectra of triangularine in the sample collected from Kahawa Sukari, dry season. C. Mass spectra of 7acetyllycopsamine in the sample collected from Kahawa Sukari, dry season. D. Mass spectra of heliosupine in the sample collected from Kahawa Sukari, dry season. E. Mass spectra of echimidine in the sample collected from Kahawa Sukari, dry season
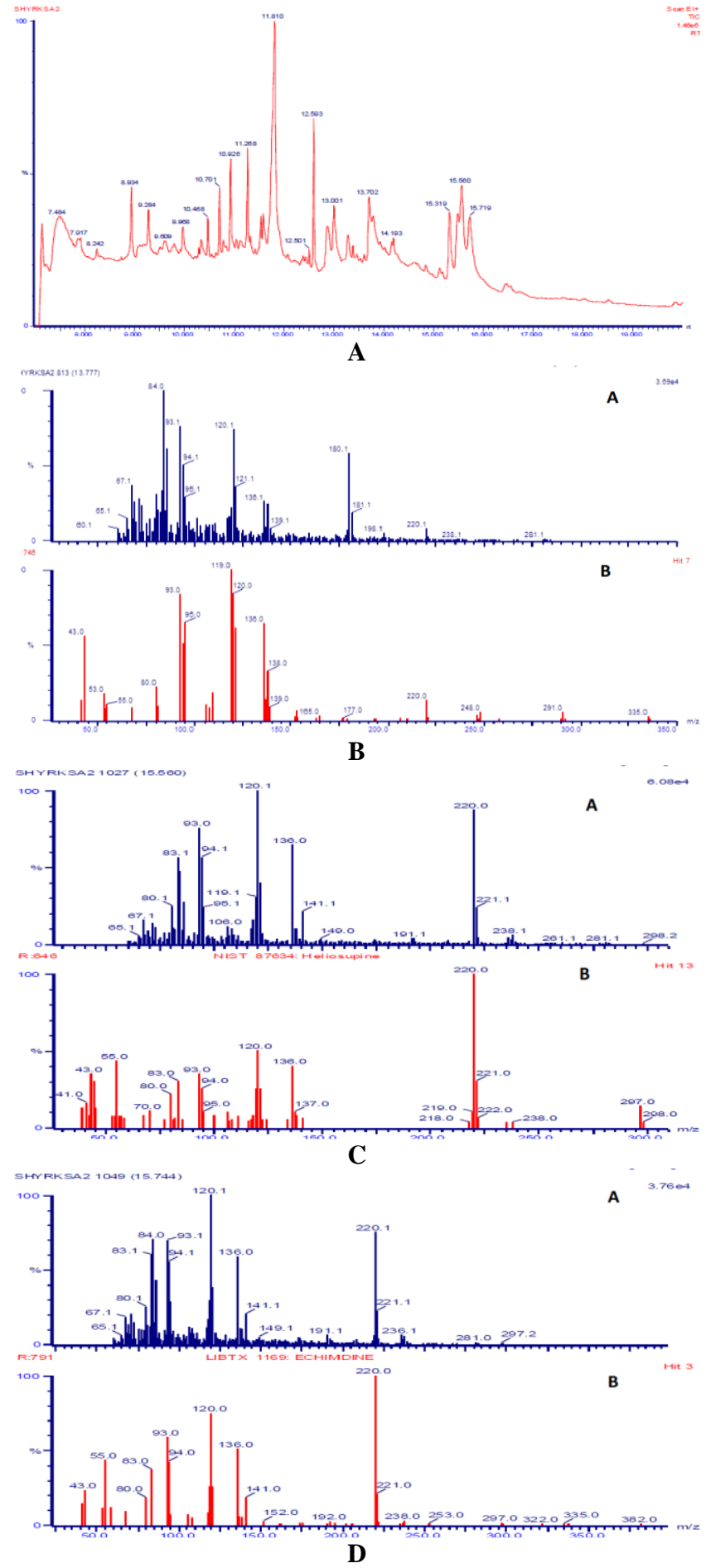

Figure S4 .A. TIC of the sample collected from Kisii, wet season B. Mass spectra of 7-acetyllycopsamine in the sample collected from Kisii, wet season. C. Mass spectra of heliosupine in the sample collected from Kisii, wet season. D. Mass spectra of echimidine in the sample collected from Kisii, wet season 

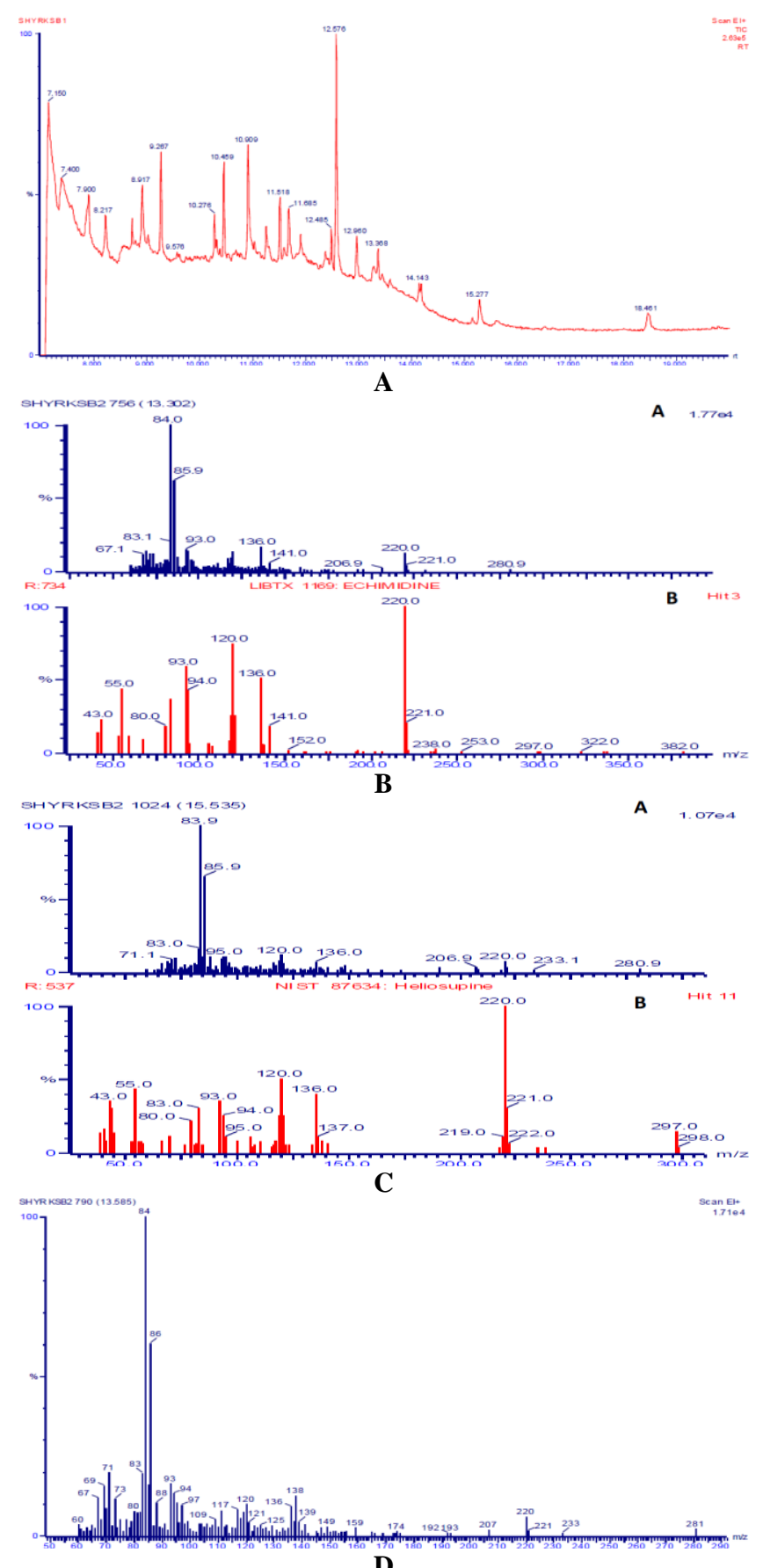

D

Figure S5 .A. TIC of the sample collected from Kisii, dry season B. Mass spectra of echimidine in the sample collected from Kisii, dry season. C. Mass spectra of heliosupine in the sample collected from Kisii, dry season. D. Mass spectra of 3-acetyllycopsamine in the sample collected from Kisii, dry season
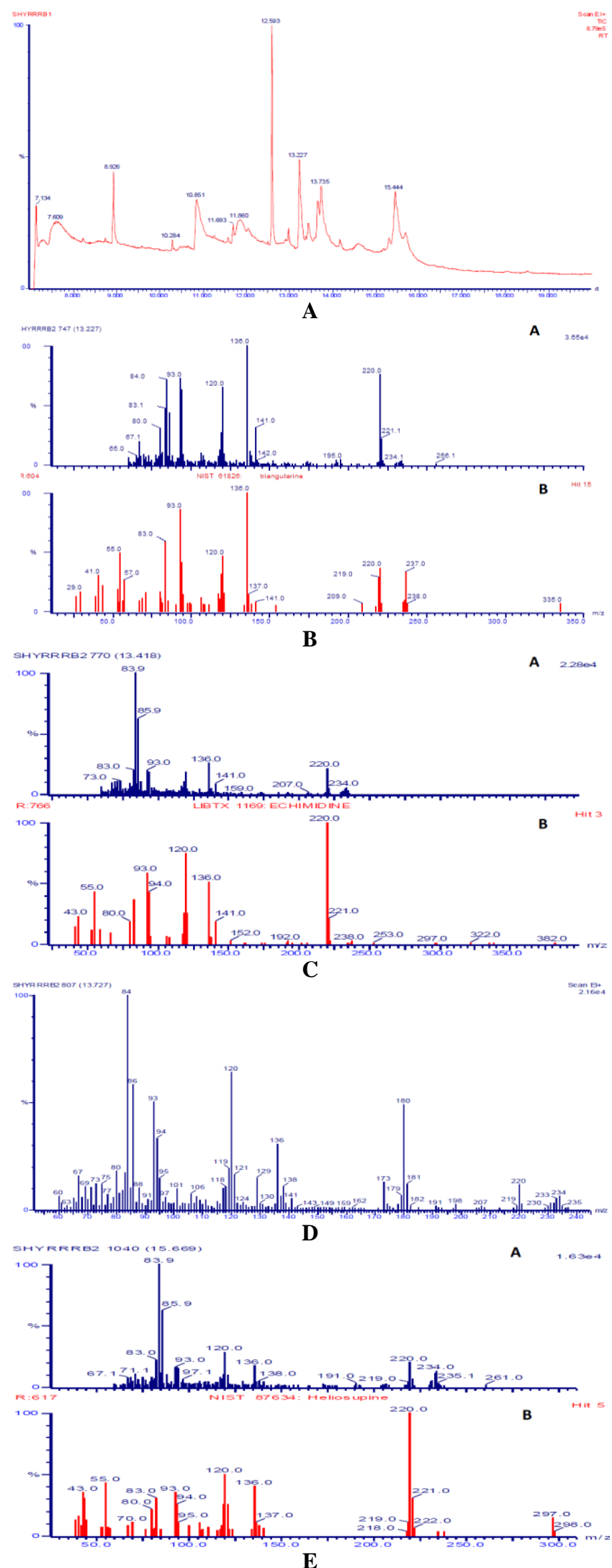

Figure S6 .A. TIC of the sample collected from Ruiru, dry season. B. Mass spectra of triangularine in the sample collected from Ruiru, dry season. C. Mass spectra of echimidine in the sample collected from Ruiru, dry season. D. Mass spectra of 7acetyllycopsamine in the sample collected from Ruiru, dry season. E. Mass spectra of heliosupine in the sample collected from Ruiru, dry season 

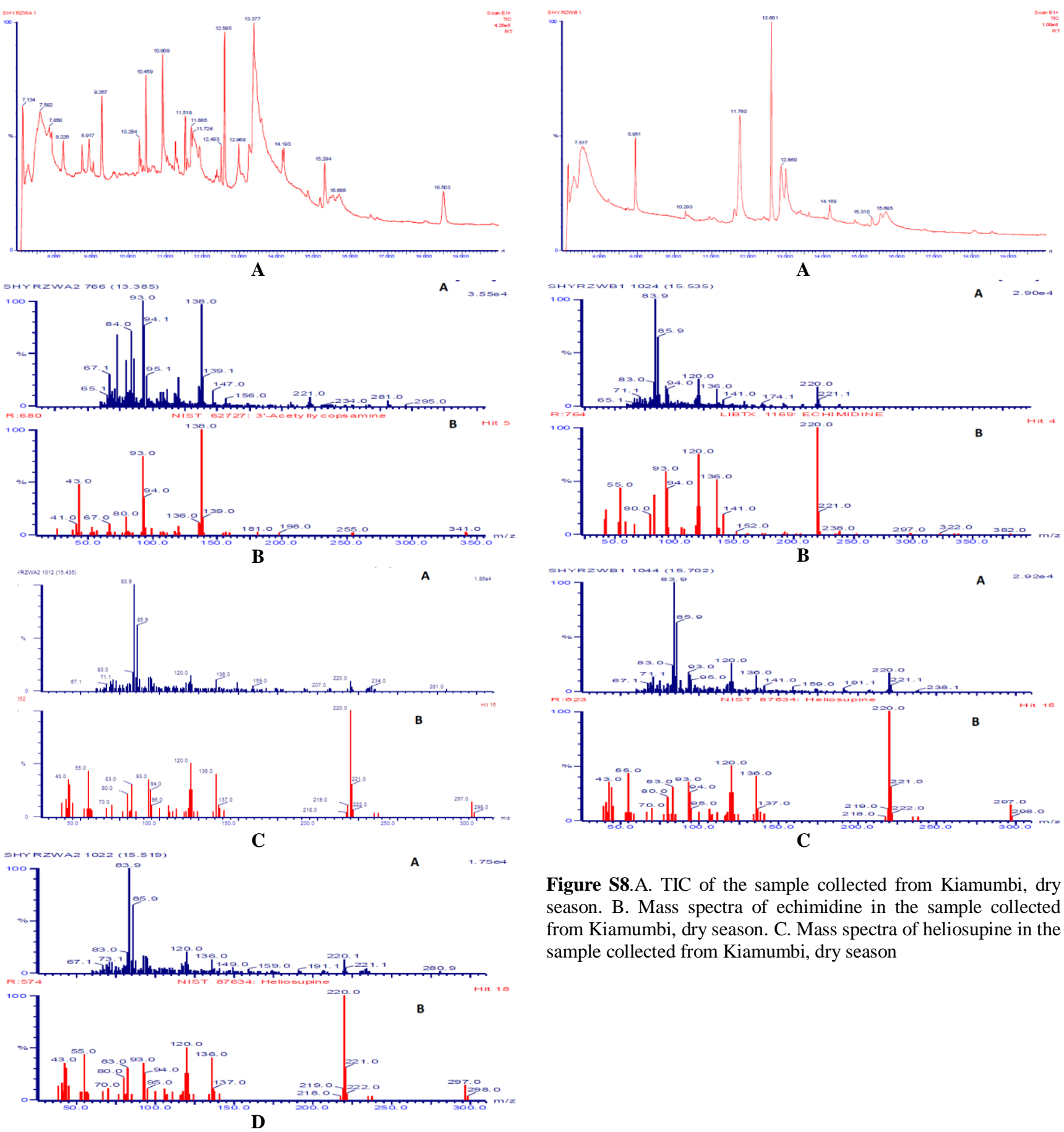

Figure S8.A. TIC of the sample collected from Kiamumbi, dry season. B. Mass spectra of echimidine in the sample collected from Kiamumbi, dry season. C. Mass spectra of heliosupine in the sample collected from Kiamumbi, dry season

Figure S7 .A. TIC of the sample collected from Kiamumbi, wet season. B. Mass spectra of 3-acetyllycopsamine in the sample collected from Kiamumbi, wet season. C. Mass spectra of echimidine in the sample collected from Kiamumbi, wet season. D. Mass spectra of heliosupine in the sample collected from Kiamumbi, wet season 

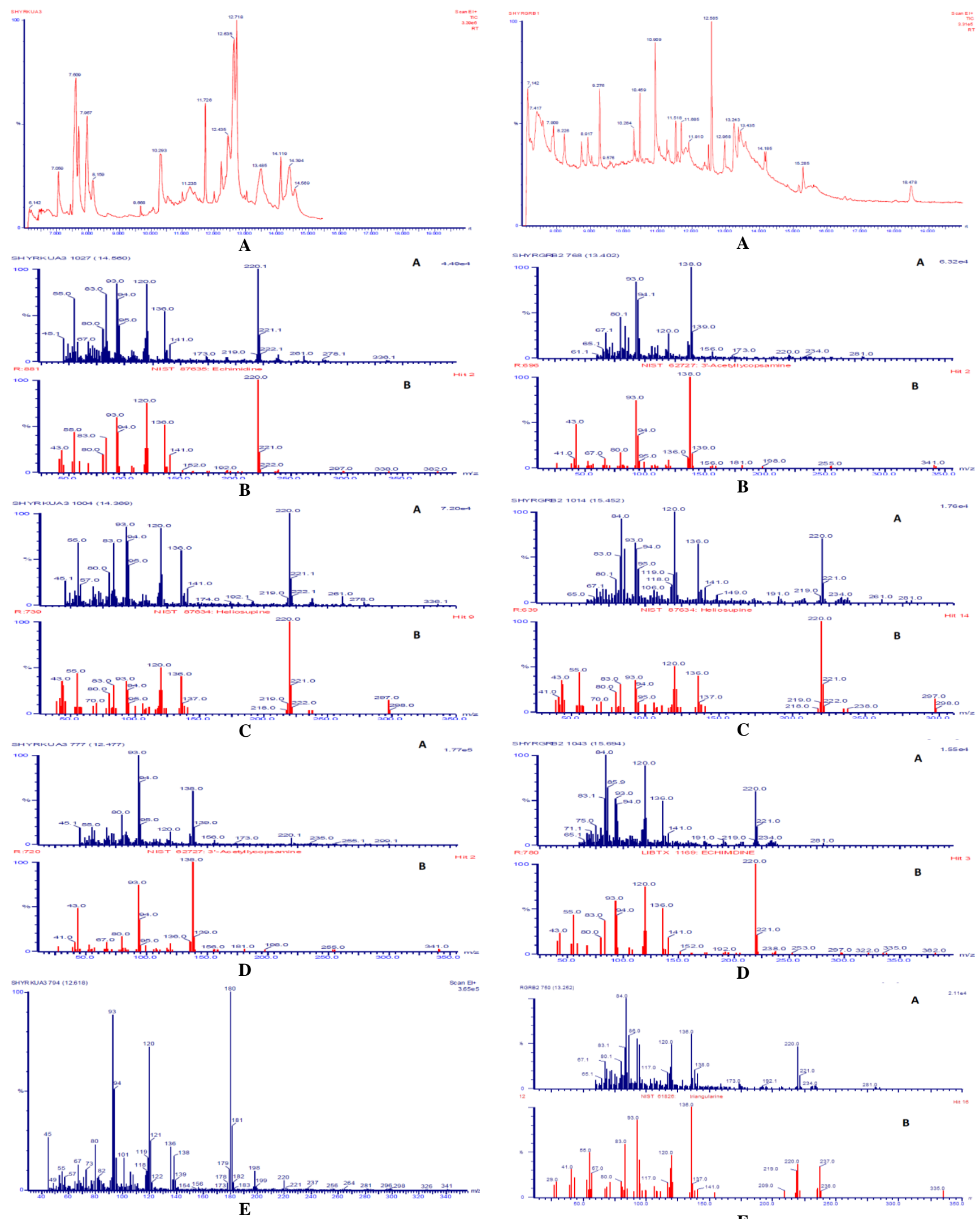

Figure S9.A. TIC of the sample collected from Kahawa Sukari, wet season. B. Mass spectra of echimidine in the sample collected from Kahawa Sukari, wet season. C. Mass spectra of heliosupine in the sample collected from Kahawa Sukari, wet season. D. Mass spectra of 3-acetyllycopsamine in the sample collected from Kahawa Sukari, wet season. E. Mass spectra of 7-acetyllycopsamine in the sample collected from Kahawa Sukari, wet season

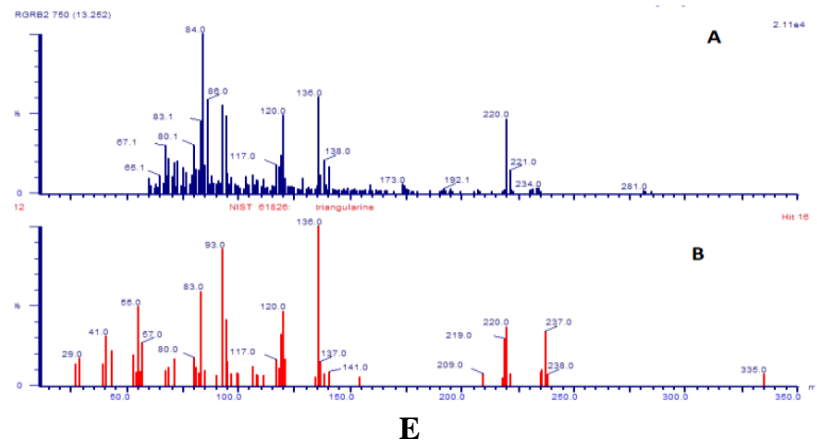

Figure S10.A. TIC of the sample collected from Githunguri, dry season. ( b) Mass spectra of 3-acetyllycopsamine in the sample collected from Githunguri, dry season. C. Mass spectra of heliosupine in the sample collected from Githunguri, dry season D. Mass spectra of echimidine in the sample collected from Githunguri, dry season. E. Mass spectra of triangularine in the sample collected from Githunguri, dry season 